\title{
MEMPERTANYAKAN KEMBALI BHINNEKA TUNGGAL IKA DI ERA POST TRUTH MELALUI MEDIA SOSIAL
}

\author{
Rizaldi Parani ${ }^{1)}$, Astrid Pramesuari' ${ }^{2)}$, Daffa Muhammad Maldiva ${ }^{3)}$, Edlyn Felicia ${ }^{4)}$ \\ ${ }^{1}$ Fakultas Ilmu Sosial dan Ilmu Politik, Universitas Pelita Harapan \\ Email: rizaldi.parani@uph.edu \\ ${ }^{2}$ Fakultas Ilmu Sosial dan Ilmu Politik, Universitas Pelita Harapan \\ Email: astridpramesuarii@gmail.com \\ ${ }^{3}$ Fakultas Ilmu Sosial dan Ilmu Politik, Universitas Pelita Harapan \\ Email: daffamaldiva15@gmail.com \\ ${ }^{4}$ Fakultas Ilmu Sosial dan Ilmu Politik, Universitas Pelita Harapan \\ Email: edlynfelicia1@gmail.com
}

\begin{abstract}
The phenomenon of post-truth appears, in which a view believed to be true is inverted and made contradictory as a new form of truth. This phenomenon appears to occur in several countries such as the United States, North Korea, the Philippines and also Indonesia. This can be seen from various actions carried out by radical organizations that question the values of Bhinneka Tunggal Ika with the desire to change these values by referring to religious values. This activity is increasingly growing in terms of followers, and further builds up on the blasphemy case accusations towards former Jakarta Governor, Basuki Tjahaja Purnama.

This research focuses on how the social media has an influence in expanding the spread of hoaxes and hate speech as an effort to destabilize the values of Bhinneka Tunggal Ika. Information and data were obtained from interviews with mass organizations often labeled radical, nongovernmental organizations and social observers.

The results of this study confirm the need for capacity building both in the form of media literacy and also the socialization of Bhinneka Tunggal Ika values through social institutions and the Government. This is intended to create strong social capital, especially in fostering a sense of trust in the context of a pluralist society in Indonesia.
\end{abstract}

Keywords: Post truth, Bhinneka Tunggal Ika, Social Media, Social Capital, Trust.

\section{Pendahuluan}

Pancasila sebagai landasan dalam bernegara memiliki nilai-nilai seperti mengakui persamaan hak, menghormati perbedaan serta kebebasan berkeyakinan, mengutamakan kepentingan bersama, gotong royong, dan menempatkan kepentingan bangsa dan negara diatas kepentingan pribadi dewasa ini terasa semakin terkikis dengan pesatnya perkembangan media sosial. Kebhinnekaan Indonesia saat ini sedang diuji dengan maraknya informasi hoaks dan ujaran kebencian yang saling menyudutkan antara golongan satu dengan golongan lainnya. Kementrian Komunikasi dan Informatika menyatakan, terdapat 800.000 situs di Indonesia yang menjadi sumber penyebaran informasi bohong dan ujaran kebencian termasuk didalamnya adalah SARACEN dan MCA (BBC, 2017).

Penyebaran berita hoaks dan ujaran kebencian di media sosial yang masif disebabkan karena platform ini dianggap paling efektif. Jumlah pengguna media sosial di Indonesia termasuk salah satu yang paling aktif di dunia. Menurut data dari APJII, menyatakan bahwa media sosial yang paling sering dikunjungi ialah Facebook dengan persentase sebesar $54 \%$ dan diikuti oleh Instagram pada posisi kedua dengan persentase sebesar 15\% (APJII, 2016). Kepercayaan masyarakat akan informasiinfomasi yang tersebar di media sosial dapat tercermin dengan terkumpulnya umat dalam gerakan aksi bela Islam.

Hal ini dapat menyebabkan masyarakat Indonesia dapat dengan cepat memasuki era post-truth, yang mana dengan mudahnya masyarakat Indonesia menyerap informasi hoaks dan juga ujaran kebencian tanpa melakukan verifikasi terlebih dahulu. Post-truth sendiri merupakan kata sifat yang mengacu pada budaya (khususnya politik), dimana argumen dan keputusan dibuat berdasarkan daya tarik emosional sehingga fakta menjadi tidak berpengaruh (Kanakath, 2017). Selain itu, menurut Nezar Patria, editor-in-chief The Jakarta Post, mengatakan 
bahwa "post-truth adalah kondisi yang terjadi ketika informasi bohong (hoaks) disebarkan untuk memancing emosi dan sentimen publik dengan menggunakan sirkulasi media digital yang kencang dan luas serta berusaha untuk mengelaborasi suatu peristiwa yang terjadi sehingga terlihat nyata (Brama, 2017)."

Sikap reaktif masyarakat di era posttruth ini ditunjukkan semakin jelas dengan munculnya serangkaian gerakan aksi bela Islam, dimulai pertama kali pada 14 Oktober 2016 yang kerap disebut aksi 1410. Tidak lama, aksi bela Islam terus berkelanjutan hingga muncul pula nama aksi-aksi lain seperti aksi 411, 212, 112, 212 Jilid II, 313 dan 55 (Agustin, 2017). Ketujuh rangkaian aksi bela Islam tersebut bertujuan untuk memenjarakan mantan Gubernur DKI Basuki Tjahaja Purnama, tidaklah lepas dari peran sosok imam besar FPI yakni Habib Rizieq Shihab. Ia dianggap sebagai sosok kharismatik yang memiliki pengaruh dan semua perkataannya dianggap benar oleh pengikutnya termasuk ketika ia menjadi pelopor gerakan aksi bela Islam. Habib Rizieq menyatakan bahwa Ahok telah menodai agama secara sengaja dan sistematis dengan tujuan untuk mempengaruhi umat muslim (Fadhil, 2017).

Menurut Eko Sulistyo, Deputi Komunikasi Politik dan Diseminasi Informasi Kantor Staf Presiden, meluasnya fenomena post-truth di Indonesia disebabkan oleh beberapa hal:

Pertama, kemajuan teknologi informasi yang tidak diimbangi oleh kapasitas adaptasi Pemerintah dan masyaralat; kedua, adanya kompetisi politik yang terus berkepanjangan sejak Pilpres 2014; ketiga, adanya dukungan dari masyarakat terhadap ideology ekstrim anti Pancasila; keempat, adanya kegelisahan terhadap perubahan dan perbaikan system yang dilakukan saat ini (Sulistyo 2017)

Dari ke-empat penyebab nampak bahwa penyebab pertama hingga ketiga merupakan hal yang paling sering terjadi di dalam konteks hubungan antar individu dalam masyarakat. Bahkan dalam kondisi menjelang Pemilu 2019, menjadi sangat penting dan tidak jarang terjadi gesekan-gesekan baik pada level antar individu, organisasi dan juga bernegara. Mudahnya terprovokasi oleh suatu informasi yang belum tentu benar menandakan lemahnya individu dalam memahami berita dan juga mengkonfirmasi ulang tentang kebenarannya.
Literasi media di era kemajuan teknologi komunikasi dan informasi diperlukan dalam rangka mendorong masyarakat untuk mempertanyakan mengapa dan bagaimana sebuah pesan dikirimkan (Alam, 2018). Selain itu, kurangnya pendidikan character building membuat kemampuan masyarakat Indonesia masih sebatas kognitif. Pendidikan moral mengenai Pancasila dan kewarganegaraan masih dianggap pelajaran yang tidak begitu penting dalam jenjang pendidikan formal. Oleh sebab itu, penekanan terhadap media literasi dan character building dipandang perlu untuk menghadapi era post-truth demi menangkal serbuan informasi hoaks khususnya di media sosial.

\section{Identifikasi Masalah}

Produksi berita hoaks paling banyak disebarluaskan menggunakan media sosial (Hutabarat, 2017). Berita hoaks dan ujaran kebencian yang dikonsumsi masyarakat seringkali berpotensi memicu konflik sosial. Maraknya berita hoaks dan ujaran kebencian di Indonesia juga disebabkan oleh kecenderungan masyarakat yang mengutamakan aspek emosional dibanding dengan fakta obyektif yang ada (Sulistyo, 2017). Penyebaran berita hoaks yang tersebar melalui media sosial memiliki potensi besar melunturkan nilai-nilai ke-Bhinnekaan yang telah digenggam erat bangsa Indonesia.

\section{Rumusan Masalah}

Melihat latar belakang dan fenomena yang telah dipaparkan sebelumnya, yang menjadi fokus penelitian bagi peneliti adalah "Bagaimana peran media sosial di era posttruth dalam melunturkan nilai ke-Bhinnekaan pasca kasus penistaan agama yang dilakukan oleh Basuki Tjahaja Purnama?"

\section{Tujuan Penelitian}

Penelitian mengenai fenomena posttruth yang terjadi pada media sosial, bertujuan untuk:

- Untuk mendeskripsikan fenomena post-truth yang terjadi pada media sosial dalam konteks masyarakat Indonesia.

- Untuk menganalisa penyebab pudarnya nilai-nilai ke-Bhinnekaan pada sebagian organisasi masyarakat di Indonesia.

\section{Objek dan Subjek Penelitian Obyek Penelitian}


Obyek dari penelitian ini adalah penyebaran berita-berita hoaks dan ujaran kebencian melalui media sosial yang berupaya untuk mengikis integritas bangsa Indonesia. Penelitian ini membatasi pada penyebaran berita-berita yang dilakukan di media sosial pasca pidato mantan gubernur DKI di Kepulauan Seribu tgl 27 September 2016 yang berujung pada jatuhnya vonis hukuman penjara selama 2 tahun terhadap yang bersangkutan pada Mei 2017.

Adapun yang menjadi fokus utama dari penelitian ini bukanlah pada muatan/konten pada setiap berita yang diperoleh dari media sosial melainkan lebih pada maksud dan tujuan dalam menyebarkan berita tersebut. Oleh sebab itu penelitian ini berusaha untuk memberikan porsi yang seimbang bagi kelompok-kelompok yang bersebrangan. Sebagai pelengkap penelitian ini juga berusaha meng-cover pendapat dari pengamat sosial/filsafat untuk bisa membantu memahami permasalahan dengan lebih proporsional.

\section{Subjek Penelitian}

Sebagai upaya pemenuhan informasi dan data yang relevan maka subyek dari penelitian ini adalah: ormas keagamaan yang bersifat radikal, lembaga swadaya masyarakat (LSM), pengamat sosial dan juga pengamat media. Penetapan subyek penelitian didasarkan atas pemahaman dan partisipasi aktif dari lembaga/individu yang berhubungan dengan topik penelitian yang diangkat.

\section{Tinjauan Pustaka}

\section{Fenomena Post-Truth di Indonesia}

Post-truth didefinisikan sebagai

konsep yang berhubungan dengan situasisituasi dimana keyakinan dan perasaan pribadi lebih berpengaruh dalam membentuk opini publik dibandingkan dengan fakta-fakta obyektif dalam suatu peristiwa yang terjadi (Banapon, 2017). Post-truth mencerminkan keadaan yang membuat batas-batas antara kebenaran dan kebohongan, kejujuran dan kecurangan, fiksi dan non fiksi menjadi tidak obyektif (Keyes, 2004).

Lahir dan terbentuknya opini publik memiliki kaitan yang erat dengan informasiinformasi yang disebarkan melalui opinion leaders. Sehingga, opinion leaders bisa menjadi salah satu agen pendorong post-truth. Opinion leaders merupakan seseorang yang sering dimintai dan menyebarkan informasi kepada masyarakat (Nurudin, 2000). Opinion leaders dapat mengadopsi ide dan pemikiran baru, mengorganisir dengan baik dan dapat menggerakan seseorang untuk melakukan sebuah tindakan tertentu atau menerima sebuah gagasan baru (Gani, 2014). Informasi yang diberikan oleh opinion leaders seringkali lebih didengar dibanding media konvensional, hal ini menandakan bahwa benar atau tidaknya informasi yang diberikan oleh opinion leaders akan mempengaruhi stabilitas sosial dan politik masyarakat Indonesia. Saat ini, para opinion leaders berebut untuk mempengaruhi masyarakat melalui media sosial (Rachmawati, 2017).

Penyebaran informasi melalui media sosial yang dilakukan oleh opinion leaders berpotensi untuk mengkotak-kotakan masyarakat, hal ini dapat dilihat dari kasus Habib Rizieq yang dinilai menghina Pancasila dan Bhineka Tunggal Ika. Imam Besar FPI tersebut menyatakan "Pancasila Soekarno keTuhanan ada di pantat sedangkan Pancasila Piagam Jakarta ke-Tuhanan ada di kepala" (Fitrahudin, 2016). Fenomena ini berhasil menimbulkan persepsi yang berbeda-beda, pernyataan ini menggugah emosi publik dan menimbulkan sekat antara pendukung Habib Rizieq dan pihak yang menganggap Habib Rizieq menghina Pancasila. Informasi yang diberikan oleh opinion leaders seringkali mengaduk emosi, menarik sentimen masyarakat, dan bahkan melunturkan nilainilai yang sejak lama digenggam oleh bangsa Indonesia, yaitu Bhinneka Tunggal Ika.

Bhinneka Tunggal Ika merupakan semboyan negara yang dipegang erat Republik Indonesia, yang berarti "Kami berbeda-beda, tapi kami tetap satu," (Santoso, 1975). Konsep Bhinneka Tunggal Ika bukanlah hal baru bagi masyarakat Indonesia. Konsep ini memiliki tujuan politik, namun juga harus dipandang sebagai kebijakan budaya yang mendasar yang dirancang untuk membangun karakter dan peradaban yang sesuai dengan bangsa Indonesia yang pluralistik (Farisi, 2014).

Semangat toleransi beragama merupakan elemen penting dalam Bhinneka Tunggal Ika. Konsep Bhinneka Tunggal Ika merupakan konsep yang menyangkut lebih dari sekedar toleransi terhadap perbedaan agama, namun juga menyangkut toleransi terhadap perbedaan fisik, budaya, bahasa, sosial, politik, ideologis, dan psikologis, 
Bhinneka Tunggal Ika mewakili sebuah gerakan menuju persatuan, berdasarkan pemahaman, perbedaan yang justru memperkaya interaksi manusia (Lalonde, 1994). Eksistensi Bhinneka Tunggal Ika dalam struktur masyarakat yang majemuk menjadi penting, namun keberadaan Bhinneka Tunggal Ika di Indonesia menjadi dipertanyakan kembali menyangkut kasus gerakan aksi bela Islam dan penyebaran berita hoaks.

\section{Media Sosial sebagai Wadah Bertumbuhkembangnya Berita Hoaks Dewasa Ini}

Media sosial memungkinkan setiap individu untuk saling berinteraksi tanpa dibatasi ruang dan waktu, individu dapat bersosialisasi dengan satu sama lain secara online, media sosial yang biasa dipakai dalam berinteraksi ialah Facebook, Twitter, Instagram (Nimda, 2012). Pesan yang disampaikan di media sosial bisa ke berbagai individu (tidak hanya satu), pesan dapat disampaikan dan diterima secara bebas, tanpa melalui gatekeeper tertentu, alur informasi yang terjadi juga sangat cepat, lebih cepat dari media konvensional (Gamble, 2010). Media sosial mendorong kontribusi dari setiap orang yang tertarik hingga mengaburkan sekat antara audience dengan media, serta memungkinan terjadinya perbincangan secara luas ataupun dua arah (Kaplan, 2010).

Bebas dan cepatnya alur informasi yang berkembang di media sosial dimanfaatkan oleh oknum-oknum yang memiliki kepentingan untuk menyebarkan berita bohong (hoaks). Hoaks merupakan pesan yang mencoba meyakinkan pembaca tentang sebuah informasi yang tidak terbukti kebenarannya dan kemudian berusaha meyakinkan pembaca untuk melakukan suatu tindakan tertentu (Hintzbergen, 2010). Munculnya berita hoaks serta ujaran kebencian merupakan sebuah fenomena yang meresahkan masyarakat, permasalahan akan menjadi semakin rumit jika hoaks diedarkan oleh sebuah akun media sosial yang memiliki banyak pengikut.

Media sosial merupakan wadah terbesar dalam penyebaran atau beredarnya berita hoaks, salah satu media sosial yaitu Facebook telah melakukan beberapa aksi untuk meredam hal ini, seperti menghapus konten yang melanggar kebijakan Facebook dan merilis fitur penangkal hoaks, namun hal ini bukanlah hal yang mudah dikarenakan penyebaran berita hoaks seringkali beredar tanpa deskripsi atau informasi yang akurat (Jeko, 2017).

\section{Human Capital \& Literasi Media}

Human capital dibangun melalui peningkatan sumber daya manusia yang menciptakan keterampilan dan kapabilitas baru yang membuat mereka mampu melakukan berbagai hal baru (Coleman, 2000). Bohlander, Snell, dan Sherman (2001) menegaskan bahwa pembentukan human capital ditekankan oleh pengetahuan, keterampilan dan kompetensi. Namun tentunya bukan sekedar pengetahuan, keterampilan dan kompetensi, tetapi pengetahuan, keterampilan, dan kompetensi yang bermanfaat bagi organisasi dan masingmasing individu dapat berkontribusi dalam peningkatan kerja organisasi.

Fenomena ini dapat menunjukkan bahwa peningkatan human capital dapat diwujudkan dengan tumbuhnya sikap kritis masyarakat terhadap informasi yang mereka dapatkan, dan dengan adanya pengetahuan mengenai literasi media. Sekumpulan perspektif yang secara aktif digunakan oleh manusia untuk mengekspos dirinya kepada media untuk menafsirkan atau menginterpretasikan makna pesan yang mereka hadapi disebut dengan literasi media (Potter, 2015). Selanjutnya Potter menambahkan bahwa, perspektif dibangun melalui struktur pengetahuan dan untuk mendapatkan struktur tersebut manusia membutuhkan 'bahan baku' dan 'alat' (Potter, 2015). Alat yang digunakan oleh manusia adalah skill mereka dan bahan bakunya adalah informasi yang didapatkan melalui media dan kehidupan nyata (Potter, 2015). Aktif dalam konteks tersebut adalah bahwa manusia menyadari suatu pesan dan secara sadar berinteraksi dengan pesan tersebut (Potter, 2015)

Kemampuan berpikir kritis terhadap isi media merupakan sebuah esensi dasar dari literasi media, dengan kemampuan ini memungkinkan seorang individu untuk mengembangkan penilaiannya sendiri yang independent terhadap isi media, literasi media juga akan menolong menumbuhkan kesadaran akan dampak media terhadap individu dan masyarakat (Silverblatt, 2001). Literasi media dapat dijadikan strategi untuk menganalisis 
dan mendiskusikan informasi yang didapati dari sebuah media.

Human capital memiliki kaitan yang erat dengan modal sosial. Peningkatan sumber daya manusia yang menciptakan kemampuan baru dalam diri seorang individu, sehingga individu tersebut dapat menerapkannya kedalam sebuah komunitas atau organisasi, dan individu-individu dengan kemampuan baru bekerjasama demi mencapai sebuah tujuan bersama (modal sosial).

Modal sosial merupakan sebuah rangkaian proses hubungan antar manusia yang didukung dengan sebuah jaringan, norma, dan kepercayaan sosial yang mendukung kerjasama sebuah kelompok untuk sebuah keuntungan dan kebaikan bersama (Cox, 1995). Modal sosial memiliki peranan yang penting dalam memperkuat kehidupan masyarakat saat ini. Rendahnya modal sosial akan dapat menghalangi segala upaya untuk mencapai kesejahteraan masyarakat (Fukuyama, 1999).

\section{METODE PENELITIAN Pendekatan Penelitian}

Penelitian ini menggunakan pendekatan kualitatif karena pendekatan ini dianggap mampu untuk menggambarkan fenomena yang berkaitan dengan upaya untuk melunturkan nilai ke-Bhinneka Tunggal Ika-an yang banyak dilakukan oleh kelompokkelompok organisasi masyarakat melalui media sosial.

Agar penelitian ini bisa mendapatkan hasil yang mendalam dan bukan hanya sekedar hal yang bersifat umum, maka penelitian ini akan mendapatkan penjelasan secara mendalam dari orang-orang yang memiliki keahlian di bidang media, sosial, dan politik serta orang yang terlibat langsung dalam rangkaian aksi bela Islam sebagai dampak dari kasus penistaan agama Basuki Tjahaja Purnama.

Metode penelitian yang akan digunakan dalam penelitian ini adalah metode penelitian deskriptif. Metode ini didasarkan oleh pertanyaan bagaimana (Gulo, 2002). Lebih lanjut, metode ini akan meningkatkan pemahaman peneliti mengenai bagaimana sebuah fenomena atau peristiwa dapat terjadi. Selain itu, metode penelitian deskriptif hanya menjelaskan situasi atau peristiwa dan tidak mencari dan menjelaskan hubungan, serta tidak membuat prediksi (Rakhmat, 1998).

\section{Metode Pengumpulan Data}

1. Data Primer

Dalam pengumpulan data primer, peneliti menggunakan metode indepth interview.

- In-depth interview

Wawancara merupakan instrumen yang digunakan untuk memperoleh data dalam penelitian ini. Menurut Bungin (2007, h. 108) in-depth interview adalah

Proses memperoleh keterangan untuk tujuan penelitian dengan cara tanya jawab sambil bertatap muka antara pewawancara dengan informan atau orang yang diwawancarai, dengan atau tanpa menggunakan pedoman wawancara, dimana pewawancara dan informan terlibat dalam kehidupan sosial yang relatif lama.

Wawancara yang dilakukan dalam penelitian ini adalah jenis wawancara semistructured, dimana wawancara yang akan dilakukan diarahkan melalui interview guidelines. Interview guidelines ini sendiri akan berisikan tentang topik permasalah dalam penelitian. Dalam wawancara yang dilakukan pertanyaan yang akan diajukan tidak terpaku pada interview guidelines, melainkan pertanyaan akan mengikuti situasi wawancara dan interview guidelines hanya akan mengendalikan alur wawancara. Wawancara dilakukan dengan empat informan, Halili (Peneliti SETARA Institute), Muhammad Syahroji (Kepala Sekretariat DPP FPI), Adek Media Roza (Head of Research \& Data KATADATA), dan Dr. Fransisco Budi Hardiman (Pengamat Sosial).

2. Data Sekunder

Dalam mengumpulkan data sekunder, peneliti menggunakan studi kepustakaan dalam mengumpulkan informasi.

- Studi Kepustakaan

Studi kepustakaan yang akan dilakukan adalah dengan mencari informasi melalui media cetak dan online yang berkaitan dengan penggunaan media sosial dalam melunturkan nilai-nilai ke-Bhinneka Tunggal Ika-an.

Metode Analisis Data 
Analisa data adalah proses penyederhanaan dan penyajian data dengan mengelompokannya dalam suatu bentuk yang mudah dibaca dan diinterpretasi (Silalahi, 2009). Analisis data yang akan dilakukan dalam penelitian ini adalah:

1. Reduksi Data

Data yang didapatkan dalam pengumpulan data berupa hasil wawancara dapat dikatakan cukup banyak. Oleh karena itu, akan dilakukan reduksi data dengan merangkum, memilih hal-hal pokok atau inti, memberikan fokus kepada hal yang lebih penting dan membuang yang tidak perlu. Ketika proses reduksi sudah dilakukan maka proses analisa data akan lebih mudah. Analisa data dilakukan dalam bentuk uraian singkat atau teks naratif dan pengelompokan data akan dilakukan dengan coding. Menurut Saldana $(2009$, h. 3$)$ coding adalah " $a$ code in qualitative inquiry is most often a word or short phrase that symbolically assigns a summative, salient, essence - capturing, and/or evocative attribute for a portion of language - based or visual data."

2. Penyajian Data

Proses penyajian data ini sendiri dapat disajikan dalam bentuk uraian singkat, tabel, dan sebagainya. Tujuan dari penyajian data ini sendiri adalah memudahkan untuk memahami apa yang terjadi, dan membantu peneliti untuk melakukan pengambilan tindakan selanjutnya dan kemudian melakukan penarikan kesimpulan.

3. Penarikan Kesimpulan

Langkah terakhir yang akan dilakukan adalah melakukan penarikan kesimpulan, yang mana proses ini dilakukan dengan menginterpretasikan pola pengelompokkan data yang sudah dilakukan melalui proses coding. Kesimpulan ini dilakukan dengan mencoba menemukan pola-pola yang tergambar melalui data yang terkumpulkan.

\section{HASIL DAN PEMBAHASAN}

\section{Penggunaan Media Sosial Menciptakan \\ Ketidakstabilan Politik}

Pada era digital saat ini, dimana teknologi berkembang dengan pesat, masyarakat sudah biasa terpapar dengan salah satu bentuk dari teknologi, yaitu media sosial. Media sosial menjadi wadah untuk berbagi informasi dengan banyak orang. Tidak dapat dipungkiri bahwa media sosial, memberikan dampak yang besar pada pengguna karena sangat efektif bahkan hingga mampu menciptakan ketidakstabilan politik. Hasil temuan penelitian menunjukkan bahwa di era post- truth, media sosial yang merupakan media baru yang menghilangkan sekat antara rasional dan emosional, dimanfaatkan untuk menyebarkan berita bohong dimana isu-isu sektarian dan keagamaan disuarakan terus menerus, dan masyarakat lebih percaya berita yang disebar di media sosial daripada media konvensional. Namun demikian, Syahroji selaku Kepala Sekretariat DPP FPI memiliki pandangan lain bahwa:

Sejak aksi bela Islam FPI tidak punya media (Facebook \& Twitter), karena medianya sudah dirampas oleh kepolisian, jadi kita hanya punya media alami seperti panggungpanggung tabligh atau gunakan hp yang ada, itu aja.

Dengan demikian, FPI berkeyakinan bahwa sebuah pesan tidak selalu memerlukan media sosial untuk dapat disebar-luaskan secara efektif. Ditambah lagi, dia mempercayai adanya kuasa supernatural yang besar yang mampu menjadikan proses penyebaran informasi efektif. Berikut adalah pernyataannya bahwa "Media sekarang itu dominan dimiliki orang kafir. Umat Islam itu cukup mengimani surat Al-Baqarah ayat 120, ini yang ngasih kabar Tuhan..."

Temuan penelitian juga menyimpulkan bahwa media sosial membuat informasi sangat mudah dicapai, termasuk informasi hoaks dan ujaran kebencian diciptakan secara sistemik, diinstrumentasikan sedemikian rupa untuk tujuan tertentu. Sudah banyak pelaku penyebaran berita bohong yang ditangkap pihak berwajib akibat perbuatannya, dan salah satunya adalah MCA (Muslim Cyber Army) dan juga kasus yang dilakukan oleh Ratna Sarumpaet. Akan tetapi, Syahroji selaku Kepala Sekretariat DPP FPI mengakui bahwa MCA adalah senjata bagi umat muslim untuk membela dan membantah segala opini 
yang menyudutkan Islam, terlepas dari hoaks tidaknya isi konten yang disebar-luaskan oleh MCA.

Hoaks membawa masyarakat pada fenomena post-truth, yang mana saat ini individu cenderung langsung mempercayai segala informasi yang sejalan dengan daya tarik emosional mereka, ketimbang fakta yang ada. Hal ini sejalan dengan apa yang Adek Media (Head of Research \& Data KATADATA), yaitu: "Informasi terus masuk, dan publik akan menganggap informasi itu sebagai sebuah kebenaran, itu yang disebut post-truth kan, kebenaran baru,". Ia juga menimbali mengatakan: "Post-truth itu terjadi karena adanya berita hoaks, karena masyarakat menerima suatu berita tanpa rasa skeptis atau kecurigaan.”. Demikian dapat disimpulkan bahwa fenomena ini dapat mengubah sebuah tatanan yang sudah ada, asal masyarakat dipaparkan pada informasi-informasi bohong yang membakar emosi atau sentimen mereka.

Hasil penelitian juga menyimpulkan bahwa opinion leaders merupakan sosok yang sangat signifikan perannya dalam menggerakan opini publik, walaupun seringkali opinion leaders menyebar informasi yang tidak seharusnya kepada publik, sehingga menimbulkan kemarahan, mengaduk-aduk emosi dan masyarakat yang sentimen satu sama lain. Hal ini membuat seseorang kerap dianggap sebagai icon atau dikultuskan, karena ia dapat mempengaruhi opini publik, yang mana nampak dari ungkapan Syahroji yang memandang Habib Rizieq sebagai sosok yang selalu benar.

\section{Mempertanyakan Nilai-nilai Bhinneka Tunggal Ika dan Hilangnya Kepercayaan Pada Masyarakat}

Indonesia merupakan negara yang memiliki keberagaman yang tinggi dan dipersatukan melalui konsep Bhinneka Tunggal Ika, yang artinya adalah 'berbedabeda tetapi tetap satu'. Sayangnya, semboyan Bhinneka Tunggal Ika yang telah mempersatukan Indonesia selama kurang lebih 73 tahun ini nampaknya mulai dipertanyakan oleh beberapa organisasi masyarakat tertentu, dan diminta untuk didefinisikan kembali. Seperti yang dilontarkan oleh Syahroji (Kepala Sekretariat DPP FPI), pernyataannya adalah sebagai berikut:

Kalau mau ngomong Bhinneka Tunggal Ika itu harus jelas sampe gini hari, Indonesia saat ini sedang krisis definisi, mereka enak aja membuat definisi, tapi sesungguhnya rapuh dalam mendefinisikan yang mereka buat.

Fenomena ini didukung oleh data yang dimiliki SETARA Institute, seperti yang dilontarkan oleh Halili:

Kebhinnekaan kita ini seperti stuck. Pelanggaran kebebasan beragama dan berkeyakinan dalam riset SETARA 11 tahun terakhir stagnan. Tidak pernah kurang dari 100 setiap tahun. Ada sudah sekitar 2000an dalam 11 tahun, saya punya datanya.

Pengamat Sosial Budi Hardiman menuturkan bahwa keadaan ini diperparah dengan kecenderungan masyarakat untuk mengikuti alur anti-mainstream, yang justru melawan konsensus mengenai Bhinneka Tunggal Ika. Pandangannya didukung oleh Adek Media selaku Head of Research \& Data KATADATA, yang mengatakan bahwa apa yang terjadi menunjukkan bahwa fenomena post truth mengakibatkan masyarakat terkotakkotak.

Namun demikian Kepala Sekretariat DPP FPI, Syahroji, justru mengatakan bahwa FPI merupakan contoh konkret dari Bhinneka Tunggal Ika, yang mana "Kebhinnekaan yang sesungguhnya itu nampak dari adanya lintas parpol, suku, bahasa semuanya yang berkumpul pada aksi bela Islam. Jadi keBhinneka Tunggal Ika-an kami sudah terbukti.

Selain nilai-nilai pada semboyan Bhinneka Tunggal Ika, konsep gotong royong yang menjadi ciri khas bangsa Indonesia juga turut dipertanyakan. Padahal, gotong royong ini memunculkan kolektivitas dan kesetaraan. Masyarakat percaya dan bekerja sama untuk mencapai suatu tujuan dan ini merupakan 'modal sosial'. Modal sosial dapat dibangun jika terdapat rasa saling percaya. Namun menurut hasil data yang diperoleh, Indonesia, yang pada awalnya menganut budaya gotong royong nampaknya mulai ada pergeseran, diakibatkan oleh rendahnya tingkat kepercayaan pada sesama dan dibangunnya nilai/kemampuan berdaya saing. Halili, selaku Peneliti SETARA Institute mengatakan bahwa "Ada hubungan timbal balik yang secara kompleks melahirkan situasi distrust, yang mendorong masyarakat kehilangan modal sosial." Lemahnya modal sosial diakibatkan 
oleh human capital yang tidak mendukung dan hal tersebut disebabkan oleh rendahnya tingkat pendidikan di Indonesia, Halili, selaku peneliti SETARA Institute mengatakan bahwa "pendidikan kita selama ini belum support untuk membangun ketahanan sosial kita."

Untuk meningkatkan modal sosial, diperlukan adanya peningkatkan tingkat literasi dalam masyarakat, sehingga meningkatkan pula kualitas sumber daya manusia. Hal ini didukung oleh Halili, Peneliti SETARA Institute, yang mengatakan bahwa:

Kalau pendidikan kita bagus kan literasi masyarakat juga meningkat. Kalau literasi masyarakat meningkat kan, kan dengan sendirinya kita tidak mau dibodohin. Kalau kita tidak mau dibodohin, kan minim kemungkinan kita untuk berkonflik.

Dengan demikian jika tingkat literasi, dalam hal ini literasi media tinggi, maka dengan otomatis masyarakat akan cenderung lebih kritis dalam mengkonfirmasi segala informasi yang didapat, dan jika masyarakat lebih mengutamakan pemikiran rasional, maka masyarakat Indonesia tidak akan mudah tersulut emosi yang berpotensi menghancurkan nilai persatuan yang sejak awal dibangun.

\section{Modal Sosial dalam Memperkuat Persatuan}

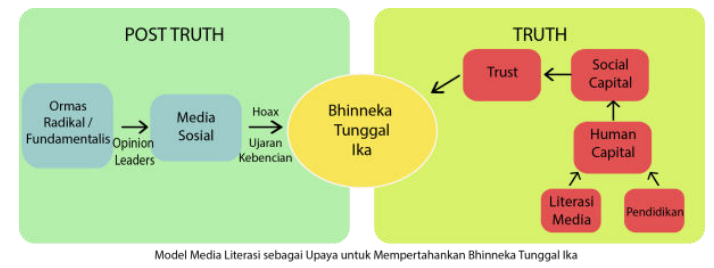

Bagan ini menunjukkan bagaimana posisi Bhineka Tunggal Ika yang dulu dipahami sebagai landasan dalam membangun nilai-nilai persatuan dan juga integritas berbangsa dan bernegara bagi masyarakat Indonesia serta disosialisasikan melalui pendidikan formal dan juga media cetak dan elektronik (truth) sekarang ini mendapat tantangan dari media sosial online. Penggunaan media sosial muncul dari beberapa kelompok radikalis radikal yang berusaha mempertanyakan dan mendefinisikan kembali tentng nilai-nilai persatuan dalam kemajemukan masyrakat yang ada (posttruth). Hal inilah yang dianggap mempengaruhi pola pikir dan perasaan masyarakat. Akibatnya adalah memunculkan pergeseran dan pengikisan dalam hal kepercayaan (trust) pada masyarakat Indonesia dan berpotensi pada munculnya konflik sosial dan politik.

Cepatnya arus informasi di media sosial memudahkan masyarakat dalam mengakses segala informasi yang ada. Namun, di sisi lain cepatnya arus informasi menimbulkan konten yang bebas dan beragam, hal ini dimanfaatkan oleh suatu kelompok atau golongan tertentu untuk menyebar luaskan berita bohong demi sebuah kepentingan, sehingga informasi yang dikonsumsi publik merupakan informasi yang tidak kredibel.

Tidak seimbangnya kemampuan adaptasi antara pemerintah dan masyarakat dengan perkembangan informasi yang terjadi, kompetisi antar aktor politik, dan munculnya kelompok masyarakat yang anti Pancasila membuat opini publik terbentuk berdasarkan daya tarik emosional daripada fakta obyektif yang ada, atau melahirkan fenomena yang disebut post-truth.

Secara tidak langsung, fenomena posttruth yang terjadi di Indonesia menjadi determinan untuk menggeser nilai-nilai Bhinneka Tunggal Ika. Hal ini dapat dilihat dari bagaimana organisasi masyarakat radikalis seperti Front Pembela Islam, menggunakan media sosial untuk membuat masyarakat mempertanyakan kembali atau meredefenisikan Bhinneka Tunggal Ika. Organisasi tersebut menyebarkan informasi yang dapat memancing sentimen publik secara masif dan terus menerus melalui media sosial, sehingga masyarakat terpicu emosinya dan mengakibatkan mereka menjadi terkotakkotak.

Sebagai contoh, bermula dari potongan rekaman video Ahok saat berkunjung ke Pulau Seribu yang diunggah oleh sebuah akun Facebook bernama Buni Yani, yang berjudul 'Penistaan Terhadap Agama?'. Video yang diunggah memotong kata 'pakai', sehingga terdapat pergeseran makna dari apa yang diucapkan sebenarnya (Rizki, 2017). Tidak lama kemudian, muncul serangkaian gerakan aksi bela Islam yang mana didalam aksi tersebut dikemukakan seruan untuk tidak memilih pemimpin yang berbeda agama dan seruan lain seperti 'Ganyang Cina' (BBC, 2017). Hal ini menggambarkan munculnya pandangan post- 
truth yang telah mengganggu nilai-nilai pluralisme yang ada dalam Bhinneka Tunggal Ika, serta mencoba menghancurkan tatanan yang sudah ada.

Pemahaman post-truth dapat diminimalisir dengan adanya pendidikan yang baik dalam masyarakat yang dimulai dari pendidikan moral (character building) hingga literasi media. Masyarakat yang memiliki pendidikan yang baik akan membentuk keterampilan atau skill yang disebut dengan human capital. Dengan adanya human capital, modal sosial akan terbentuk seiring dengan kerja sama antar individu yang berkualitas untuk mencapai suatu tujuan tertentu. Modal sosial menciptakan rasa percaya (trust) satu sama lain. Diawali dengan pendidikan yang bermutu, sehingga masyarakat dapat semakin berpikir kritis dalam menganalis apakah sebuah berita benar atau salah, sehingga masyarakat kemudian dapat menggunakan media sosial dengan arif.

\section{KESIMPULAN}

Konten informasi dalam media sosial seringkali disalahgunakan oleh suatu kelompok tertentu dalam menyebarluaskan berita bohong dan ujaran kebencian untuk sebuah kepentingan. Kecenderungan masyarakat yang langsung mempercayai segala informasi dalam media sosial dan juga didorong oleh daya tarik emosional mereka melahirkan fenomena post-truth. Hal inilah dilakukan oleh organisasi masyarakat radikalis seperti Front Pembela Islam (FPI), melalui pemimpinya Habib Rizieq untuk membuat masyarakat terkotak-kotak dan mempertanyakan kembali atau meredefenisikan Bhinneka Tunggal Ika. Fenomena post-truth telah mengganggu nilainilai pluralisme yang terdapat dalam Bhinneka Tunggal Ika, serta menghancurkan tatanan yang sudah ada.

Maka dari itu, untuk bisa menjaga keutuhan dan persatuan bangsa maka pemahaman post-truth perlu diminimalisir melalui pembentukan modal sosial yang kuat, yang mana bisa membentuk kepercayaan yang tinggi di antara masyarakat dan kerja sama baik antar individu yang berketerampilan guna mencapai suatu tujuan bersama. Pembentukan modal sosial diawali dengan membangun landasan human capital yang dapat diperoleh melalui pendidikan yang bermutu, mulai dari pendidikan moral hingga literasi media, agar kemudian masyarakat dapat menggunakan media sosial dengan arif.

\section{REFERENSI}

Agustin, D. (2017). Ini 7 Rangkaian Aksi Bela Islam Sebelum Ahok Divonis 2 Tahun Penjara. Diakses pada 14 Maret 2018, dari http://nasional.republika.co.id/berita/nasional/ hukum/17/05/10/opp5r4330-ini-7-rangkaianaksi-bela-islam-sebelum-ahok-divonis-2tahun-penjara-part2.

Alam, S. (2018). Post Truth dan Literasi Media. Diakses pada 12 Maret 2018, dari http://www.mediaindonesia.com/news/read/14 0705/post-truth-dan-literasi-media/2018-0115.

Banapon, M. (2017). Post Truth dan Media Sosial. Diakses pada 27 Februari 2018, dari https://www.qureta.com/post/post-truth-danfenomena-media-sosial.

Baran, J, S. (2017). Pengantar Komunikasi Massa: Melek Media dan Budaya ( $5^{\text {th }}$ ed.). Jakarta: Penerbit Erlangga.

Basuki, D. (2017). Era Post-Truth: Kebenaran Jadi Komoditas. Diakses pada 27 Februari 2018, dari https://indonesiana.tempo.co/read/107184/201 7/01/24/desibelkoe/era-post-truth-kebenaranjadi-komoditas.

BBC. (2017). Kasus Saracen: Pesan Kebenciandan Hoax di Media Sosial 'Memang Terorganisir'. Diakses pada 15 Maret 2018, dari http://www.bbc.com/indonesia/trensosial41022914.

Brama, A. (2017). Meretas Post Truth. Diakses pada 27 Februari 2018, dari https://geotimes.co.id/submission/comniphore/ meretas-post-truth/.

Cox, E. (1995). A Truly Civil Society. Diakses pada 16 Maret 2018, dari http://www.mapl.com.au

Fadhil, H. (2017). Habib Rizieq: Ahok Nodai Al Quran, Nodai Agama Islam. Diakses pada 12 Maret 2018, dari https://news.detik.com/berita/d3434124/habib-rizieq-ahok-nodai-alqurannodai-agama-islam?hash $=20170228$. 
Fitrahudin, H. (2016). Dianggap Hina

Pancasila, Habib Rizieq Dipolisikan

Sukmawati Soekarnoputri. Diakses pada 14

Maret 2018, dari

https://news.detik.com/berita/d-

3330943/dianggap-hina-pancasila-habib-

rizieq-dipolisikan-sukmawati-soekarnoputri.

Fukuyama, F. (2000). Social Capital and Civil Society. IMF Working Paper. WP/00/74.

Gani, P. (2014). Opinion Leader. Diakses pada 14 Maret 2018, dari

http://www.lspr.edu/pritakemalgani/opinionleader/.

Gamble, T. \& Gamble, M. (2012).

Communication Works ( $11^{\text {th }}$ ed.).

Pennsylvania: McGraw-Hill Higher

Education.

Gulo, W. (2002). Metode Penelitian. Jakarta:

Grasindo.

Hutabarat, S. (2017). Hoaks di Facebook.

Diakses pada 14 Maret 2018, dari

http://mediaindonesia.com/index.php/podium/r

ead/1004/hoaks-di-facebook/2017-09-04.

Iman, N. (2016). Post-Truth dan Medsos di Indonesia. Diakses pada 14 Maret 2018, dari http://www.republika.co.id/berita/koran/opinikoran/16/12/15/oi7ss211-posttruth-danmedsos-di-indonesia.

Irwansyah. (2017). Pasca Kebenaran Riset dan Tata Kelola Komunikasi. Diakses pada 2 Maret 2018, dari

http://www.mediaindonesia.com/news/read/11 1599/pascakebenaran-riset-dan-tata-kelolakomunikasi/2017-07-06\#.

Jeko, R. (2017). Ini Tantangan Facebook Berantas Berita Hoax di Indonesia. Diakses pada 14 Maret 2018, dari http://tekno.liputan6.com/read/3150597/initantangan-facebook-berantas-berita-hoax-diindonesia.

Kahari, M. (2017). HUT RI 72, Tingkat Literasi Indonesia. Diakses pada, 3 Maret 2018, dari https://geotimes.co.id/submission/hutri72/hutri 72-tingkat-literasi-indonesia/.

Kanakath, P. (2017). Talking About Post Truth Politics and Education. Diakses pada 27

Februari 2018, dari

http://www.thejakartapost.com/life/2017/04/07

/talking-about-post-truth-politics-andeducation.html.

Kaplan, A, M. \& Haenlein, M. (2010). Users of The World, Unite! The Challenges and Opportunity of Social Media. Business Horizons, 53, 59-68.

Keyes, R. (2004). The Post Truth Era: Dishonesty and Deception In Contemporary Life. New York: St. Martin's Press.

Potter, W. (2005). Media Literacy ( $3^{\text {rd }} e d$.). California: Sage Publications, Inc.

Rakhmat, J. (1998). Metode Penelitian Komunikasi Dilengkapi Contoh Analisis Statistik. Bandung: PT Remaja Rosdakarya Offset.

Setyani, T. (2009). Bhinneka Tunggal Ika Sebagai Jati Diri Bangsa. Paper dipublikasikan di Konferensi Nasional dan Pembentukan Organisasi Profesi Pengajar Bahasa, Sastra, Budaya, dan Seni Daerah seIndonesia. Yogyakarta: Universitas Gajah Mada.

Silalahi, U. (2009), Metode Penelitian Sosial. Bandung: PT Refika Aditama.

Subiakto, H. (2017). Fakta Dapat Kalah di Era Post Truth. Diakses pada 14 Maret 2018, dari https://legaleraindonesia.com/fakta-dapatkalah-di-era-post-truth/.

Sulistyo, E. (2017). Media Sosial dan Fenomena Post Truth. Diakses pada 27 Februari 2018, dari http://ksp.go.id/mediasosial-dan-fenomena-post-truth/index.html.

Tarigan, K. (2016). Survey SRMC: 45,2 Persen Masyarakat Setuju Ahok Menistakan Agama. Diakses pada 12 Maret 2018, dari https://news.detik.com/berita/d3366806/survei-smrc-452-persen-masyarakatsetuju-ahok-menistakan-agama. 
Tribunnews. (2017). Oh, Ternyata Penyebar Berita Hoax Manfaatkan Peralatan Canggih, Ada Pesanan Kepentingan. Diakses pada 14 Maret 2018, dari

http://www.tribunnews.com/nasional/2017/02/

23/oh-ternyata-penyebar-berita-hoax-

manfaatkan-peralatan-canggih-ada-pesanankepentingan. 